\title{
How does Innovation Contribute to a Sustainable Agri-Food Chain? A European Overview
}

\author{
Cristiana-Ioana Șerbănel ${ }^{1}$ \\ 1) The Bucharest University of Economic Studies, Bucharest, Romania. \\ E-mail: cristiana.serbanel@rei.ase.ro
}

\begin{abstract}
Please cite this paper as:
Șerbănel, C.I., 2021. How does Innovation Contribute to a Sustainable AgriFood Chain? A European Overview. In: R. Pamfilie, V. Dinu, L. Tăchiciu, D. Pleșea, C. Vasiliu eds. 2021. $7^{\text {th }}$ BASIQ International Conference on New Trends in Sustainable Business and Consumption. Foggia, Italy, 3-5 June 2021. Bucharest: ASE, pp. 853-861 DOI: 10.24818/BASIQ/2021/07/107
\end{abstract}

\begin{abstract}
The sustainability concept gained currency in all the economic sectors, especially in the agriculture industry, admitting its vital role in providing essential food, feed, and fuels to human beings. Due to resource scarcity, sustainability is progressively present among governmental, researchers, and international organizations' agendas. This paper evaluates innovation's role in building a sustainable agriculture industry by considering how committed European governments are to the present concept. The investigation adopted a two-fold methodology: (1) a quantitative study using data extracted from the Eurostat database to analyze governmental support to agricultural research and development from 2010 to 2019 and (2) a qualitative approach which consisted of examining 73 projects funded by the European Investment Bank in the Agriculture, Fisheries and Forestry sector during 2010-2021. The scope of the latter approach was to identify the frequency of the initiatives related to innovation and research and development activities. According to the results, Germany, United Kingdom, Spain, and France are the countries that obtained the most significant support from national governments for RandD activities. Even though Croatia, Malta, and Latvia recorded the most considerable growth in terms of percentual evolution, these nations listed the lowest budget in terms of value. As for the European Investment Bank funded projects in the agriculture sector, only 13 out of 73 projects were directly related to innovation. The value of the present study comes as a signal for the European nations to review their priorities and redesign the funding schemes where possible to support a sector that has a direct role in human perpetuation.
\end{abstract}

\section{Keywords}

Sustainability, agriculture, innovation, research and development, Europe, agri-food supply chain, European Investment Bank

DOI: $10.24818 / B A S I Q / 2021 / 07 / 107$

\section{Introduction}

Sustainability is an omnipresent concept directly linked to all the economic realms, which implies "the development that meets the needs of the present without compromising the ability of future generations to meet their own needs." (United Nations, 1987)

From a general perspective, each sector contributes to the well-functioning of the economy and human well-being. Still, agriculture has a primordial role by providing the essential feed, food, and fuels from ancient times to the present. In such circumstances, a global embracement of sustainable agriculture is mandatory. The theory of sustainability is relatively a brand-new idea; the phrase "sustainable agriculture" was coined by the Australian Economist Gordon McClymont, and it started to gain popularity in the late 1980s. A reinvention of the agriculture sector will make it possible to generate food for the entire population without compromising its sustainability. (El Bilali, 2019), (Vermunt, et 
al., 2020). The world population is rapidly growing, and it is expected to reach 8.5 billion in 2030 , increase further to 9.7 billion in 2050, and 10.9 billion in 2100. (United Nations, 2019) Under these conditions, business-as-usual in global agri-food systems is no longer viable.

Defining agricultural sustainability is a challenging assignment. (Lampridi, et al., 2019). In line with this, there is a general agreement that agricultural sustainability should at a minimum include three fundamental pillars of sustainable development by assessing concurrently environmental, economic, and social challenges related to agricultural practices. (Van Pham and Smith, 2014).

Innovation plays a crucial function in creating a sustainable agri-food sector. At the European level, the industry's annual private investment in Research and Development (RandD) is EUR 3 billion, an amount knowingly lower than the health sector (EUR 41 billion) or the information technology sector (EUR 34.3 billion). Less than $50 \%$ of all the European Union (EU) agri-food companies initiated innovation activities over the 2017-2019 period, while only 9\% transformed in core areas such as products, processes, and technology. (European Investment Bank, 2019). In a press release in June 2018, a budget of EUR 10 billion was provisioned for the 2021-2027 period set for RandD projects in food, agriculture, bioeconomy, and rural development. (European Commission, 2018a) The European Commission's Research and Innovation Program "Horizon 2020" and the United Nations' set of sustainable goals asserted the organizations' commitment towards innovation, food security, and sustainable agriculture. (European Commission, 2011); (United Nations, 2015).

This paper proposes to appraise the European orientation towards innovation and RandD activities in agriculture using a two-approach perspective: (1) by analyzing the evolution of governmental budget orientated towards RandD activities and (2) by screening the European Investment Bank's funded projects related to innovation and RandD operations.

\section{Literature review}

There is continuously mounting concern about sustainability concepts applied in the agricultural field. The author conducted a wide-ranging analysis of "agriculture" and "sustainability" terms for the 19752021 period and 2000-2021 via the Web of Science database. The results indicated that the number of scientific papers raised exponentially, starting with 2000. From 2000 to 2021, there were a total of 11.497 published papers. Additionally, the role of innovation for sustainable agriculture started to become present in 2010. Only 75 scientific reports, including in their topic "agriculture" and "sustainability" and "innovation", were published before 2010, while after 2010, the number rocketed to 754 . These articles examined the sustainability concept in agriculture considering various layers: a general view, regional or country-level; considering the crop field; analyzing various factors such as technology, business model, farmers behavior, green logistics, and others.

A general perspective of sustainable agri-food chains was brought into discussion by (Barth, et al., 2017), (Mangla, et al., 2018), (Naik and Suresh, 2018), (Bertoni, et al., 2018). More in-depth, researchers analyzed the role of various factors contributing to sustainability in agriculture such as: (Sharpe \& Barling, 2019) the role of ethics and responsibility; (Lara, et al., 2019) the role of socialecological innovations and traditional ecological knowledge; (Blanc, et al., 2019) the use of bio-based plastics; (Nastis, et al., 2019) the impact of farmers' behavior towards sustainable practices; (Elisante, et al., 2019) introduced the impact of pollinators for sustainable food security, while (Trivellas, et al., 2020) green logistics management.

Moreover, the role of innovation in supporting a sustainable agricultural sector was discussed under distinct perceptions. For instance, (Jones-Garcia and Krishna, 2021) analyzed the impact of sustainable intensification technologies in the maize systems. (Yadav, et al., 2021) discussed the internet of things, while (Ashraf, et al., 2021) pointed out the influences of innovations and nanoscience in agriculture. (Rana, et al., 2021) reminded of the blockchain technology, (Fischer, et al., 2012) introduced the transformative system innovation, and (Ulvenblad, et al., 2019) analyzed the role of innovation in Swedish agricultural production.

Other papers offered comparative studies between countries or regions (Ilieva \& Hernandez, 2018); (Vasa, et al., 2018), while some authors depicted the subject of sustainability in agriculture at country 
or group of countries level (Perez-Mesa, et al., 2019); (Patidar, et al., 2018); (Adhikari and Prapaspongsa, 2019); (Salazar, et al., 2020); (Zollet and Maharjan, 2021).

Furthermore, sustainable agri-food systems were investigated at the crop level as follows: honey (Pippinato, et al., 2020); cocoa (Moreno-Miranda, et al., 2019); (Lerner, et al., 2021); Parmigiano Reggiano (Arfini, et al., 2019); legume-based food (Balazs, et al., 2021); wine industry (Pullman, et al., 2010); (Martucci, et al., 2019).

\section{Research methodology}

The study was motivated by the following research questions: Is innovation vital for a sustainable agrifood chain? How present are the governments of EU's member states to the role of innovation for a sustainable agri-sector? Which was the evolution of governmental RandD budgets for the agricultural sector from 2010 to 2019? How many projects supported by the European Investment Bank (EIB) bank in the Agriculture, Fisheries, Forestry field involved RandD activities?

The present paper addressed the research using a two-fold approach. On the one hand, a quantitative analysis was conducted using data extracted from Eurostat Database. The study selected the government support to agricultural research and development Index (GBAORD) for the 2010-2019 period. All the 28 European Union (EU) member states were selected, even if the research United Kingdom (UK) is not anymore an EU member state. On the other hand, the qualitative research was approached to identify the Agriculture, Fisheries, Forestry sector projects funded by the European Investment Bank. The selection of the period time was between 2010 to 2021, while the coverage area included Eastern Europe, Southern Caucasus. A total of 73 projects were found and each of the projects' summaries sheets were analyzed. Only the projects that included "innovation," "Research and Development," "technology," "technical" (only if related to technology in context) were selected.

Even if RandD leads to innovation and the activities can exist independently and mixed, the concepts were considered alternates.

\section{Results and discussion}

The agricultural sector has an essential contribution to the European economy. Agriculture generates EUR 1.45 trillion revenue, which corresponds to $9 \%$ of the EU's gross domestic product and encompasses more than $15 \%$ of the European manufacturing industry. On the global trading map, the EU is the most significant agri-food exporter. (European Investment Bank, 2019) The global food chain is currently disrupted by several challenges: a growing population world, climate change, and resource scarcity. In addition, the COVID-19 pandemic caused additional pressure on the entire agricultural value-chain sector.

Innovation lead by Research and Development activities represents the key for agricultural rapid and high-impact solutions, which are meant to address fragmentation, align programs to adopt a food system that satisfies multiply objectives simultaneously, slow implementation of new technologies ensures policy coherence. (European Commission, 2018) In January 2016, the EU published the longterm strategy for agricultural research and innovation. The leading program is Horizon 2020, covering the 2018-2020 period and further than 2020. In line with this, the European innovation partnership operational groups for agriculture (EIP-AGRI) was launched to contribute to the EU's strategy 'Europe 2020 ' for smart, sustainable, and inclusive growth.

Figure 1 indicates the top $10 \mathrm{EU}$ member states that received the most considerable governmental support in terms of value for agricultural RandD in the 2010-2019 period. Germany ranks first, receiving the most significant contribution of EUR 7.983 million in total, with a percentual increase of $16 \%$ in 2019 compared to 2010. The second ranking is the UK, with a total budget of EUR 4.352 million and an $11.5 \%$ increase in funding. UK was closely followed by Spain (EUR 4.348 million) and France (EUR 3.462 million). Notably, Spain registered a $23.4 \%$ drop in the total RandD budget directed to the agri-sector, France, a $0.1 \%$ increase, Italy an $8.1 \%$ decrease, while Norway registered a remarkable increase of $36.7 \%$. 


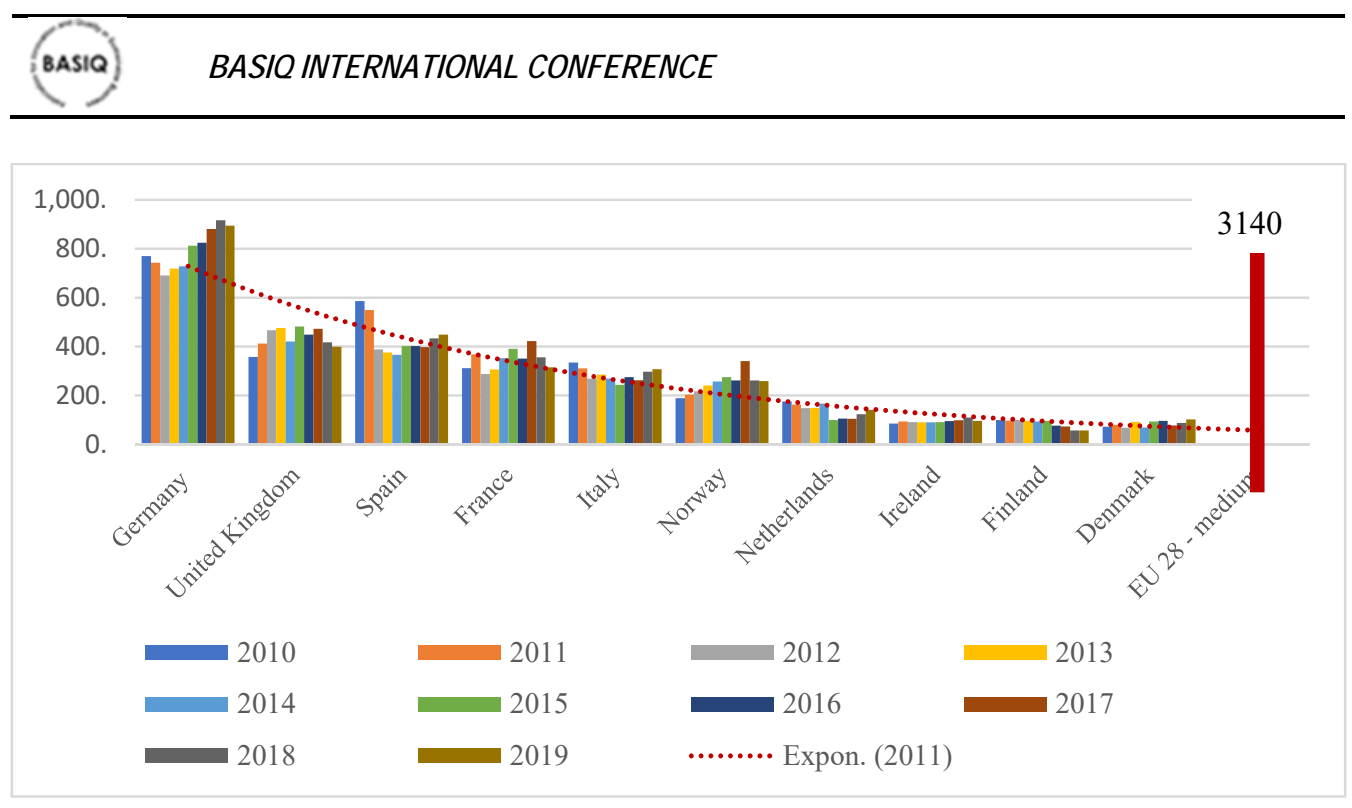

Figure no. 1. Government support to agricultural research and development (million euro) top 10 countries

Source: Author's calculations based on data extracted from EUROSTAT (2021)

At the opposite pole, the top 10 European member states that collected the smallest amount in value from government directed to agricultural RandD were identified. Conversely, although the states are the least among the European countries in terms of the total value, these states registered the most significant percentual increase in funding. These slight-value budgets may also be different because of differences in arable surfaces. Noteworthy, in terms of percentual increases, Croatia registered a $353.2 \%$ upsurge in the government budget for RandD in agriculture, Malta a $+247.5 \%$, Latvia a $+159.14 \%$, and Bulgaria a $+78.8 \%$. (Figure 2) Also, among the countries which do not belong to any of these rankings, there can be mentioned: Poland (+46.2\%), Belgium (+77\%), Greece (+96\%), Hungary (+106.6\%), and Romania (-63.3\%).

Overall, as the final figures indicate, governments directed expanding attention towards RandD in agriculture. There was a significant average increase of $37.4 \%$ in 2019 compared to 2010 for the examined EU member states.

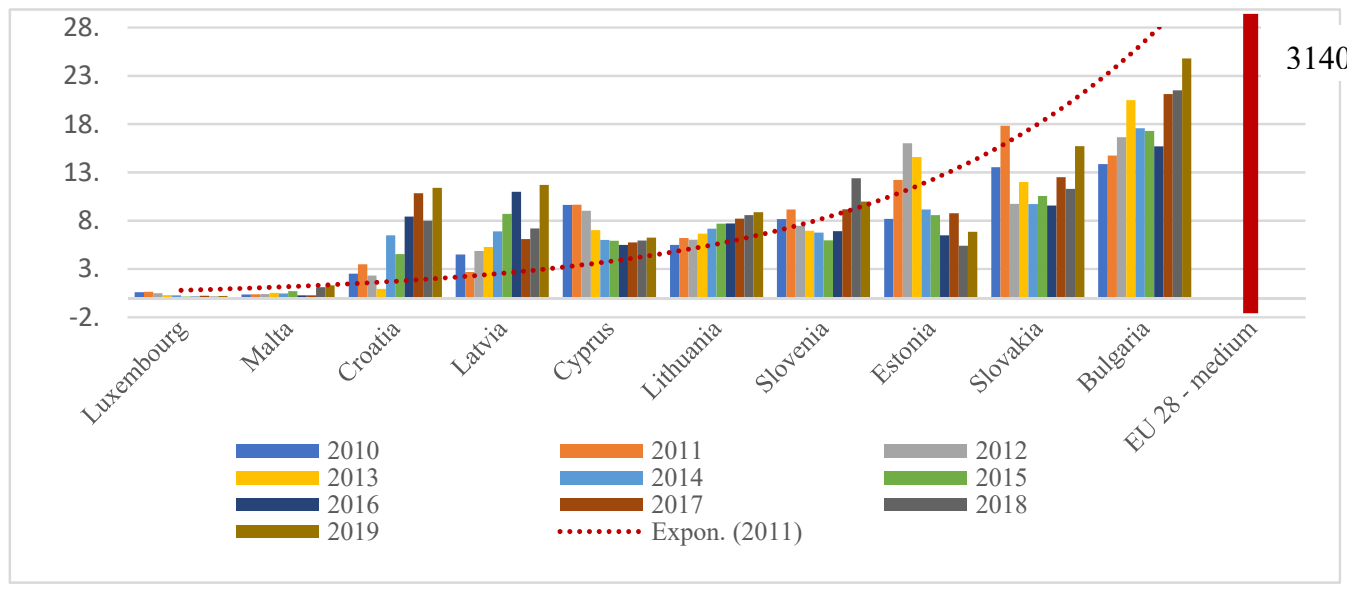

Figure no. 2. Government support to agricultural research and development (million euro) top 10 least countries

Source: Author's calculations based on data extracted from EUROSTAT (2021)

The European Investment Bank represents one of the EU's primary lending sources and one of the largest climate finance providers, committed to sustainable growth within the EU and abroad. From a 
general perspective, according to the latest available data, the structure of the European Fund for Strategic Investments (EFSI), an initiative launched jointly by the EIB, had the following structure: $33 \%$ - smaller companies; RDI - 26\%; Energy - 26\%; Digital - 9\%; Transport - 6\%; Social Infrastructure $-5 \%$; Environment and resource efficiency $-4 \%$; Bioeconomy $-1 \%$. (European Investment Bank, 2021)

Table 1: European projects financed by the EIB in the Agriculture, Fisheries, Forestry sector related to innovation and RandD (2010-2021)

\begin{tabular}{|c|c|c|}
\hline Project & Primary Objective and Other Relevant Information & Country \\
\hline $\begin{array}{l}\text { AVRIL RDI } \\
\text { PROGRAMME } \\
22 / 12 / 2021\end{array}$ & $\begin{array}{l}\text { The project will support the Promoter's research, development and } \\
\text { innovation (RDI) industries targeting the development and production of } \\
\text { protein for food and feed purposes from oilseed yield and bio-based } \\
\text { materials replacing fossil sources for chemical use. } \\
\text { EIB finance: EUR } 50 \text { million; Total Cost: EUR } 134 \text { million }\end{array}$ & France \\
\hline $\begin{array}{l}\text { EUROPEAN } \\
\text { CIRCULAR } \\
\text { BIOECONOMY } \\
\text { FUND } \\
21 / 08 / 2020 \\
\end{array}$ & $\begin{array}{l}\text { The project comprises equity participation in a fund investing into } \\
\text { innovative and circular bioeconomy businesses and projects covering the EU } \\
\text { Member States and Horizon } 2020 \text { Associated Countries. } \\
\text { EIB finance: EUR } 100 \text { million; Total Cost: EUR } 250 \text { million }\end{array}$ & $\begin{array}{l}\text { EU } \\
\text { Member } \\
\text { States }\end{array}$ \\
\hline $\begin{array}{l}\text { KWS SAAT RDI } \\
26 / 06 / 2020\end{array}$ & $\begin{array}{l}\text { The project aims to fund research, development, and innovation (RDI) } \\
\text { activities related to the creation, registration, development, and } \\
\text { commercialization of novel field crop and vegetable seed diversity. } \\
\text { EIB finance: EUR } 200 \text { million; Total Cost: EUR } 583 \text { million }\end{array}$ & $\begin{array}{l}\text { France, } \\
\text { Germany, } \\
\text { Italy, The } \\
\text { Netherlan } \\
\text { ds }\end{array}$ \\
\hline $\begin{array}{l}\text { FRENCH SEEDS } \\
\text { RandD } \\
18 / 12 / 2019\end{array}$ & $\begin{array}{l}\text { The project objective is to support the promoter's Research, Development, } \\
\text { and Innovation (RDI) activities related to the creation, registration, } \\
\text { development, and commercialization of novel field crop and vegetable seed } \\
\text { diversity for their use in agriculture. } \\
\text { EIB finance: EUR } 170 \text { million; Total Cost: EUR } 428 \text { million }\end{array}$ & France \\
\hline $\begin{array}{l}\text { AGRICULTURA } \\
\text { L } \\
\text { MODERNISATI } \\
\text { ON AND } \\
\text { INNOVATION } \\
23 / 11 / 2017\end{array}$ & $\begin{array}{l}\text { The project consists of several investments to enlarge grain and sugar storage } \\
\text { capability. The EIB loans were also expected to finance an information } \\
\text { technology solution to enhance a range of agricultural procedures as part of } \\
\text { the InnovFin scheme. } \\
\text { EIB finance: EUR } 36 \text { million; Total Cost: EUR } 72 \text { million }\end{array}$ & Ukraine \\
\hline $\begin{array}{l}\text { SCA OSTRAND } \\
\text { MILL } \\
\text { EXPANSION } \\
\text { AND } \\
\text { FORESTRY } \\
15 / 11 / 2017\end{array}$ & $\begin{array}{l}\text { Through higher energy efficiency and innovative process optimization, the } \\
\text { project involves: (i) the finance of selected renewable energy, energy } \\
\text { efficiency, and environmental safeguard measures within an investment } \\
\text { action in Sweden by upgrading a pulp mill (ii) the replanting and restoration } \\
\text { of roughly } 68,000 \text { ha of forest, the building of } 4,250 \mathrm{~km} \text { of forest roads and } \\
\text { an improvement of five forest terminals. } \\
\text { EIB finance: EUR } 150 \text { million; Total Cost: EUR } 684 \text { million }\end{array}$ & Sweden \\
\hline $\begin{array}{l}\text { TOMATO } \\
\text { PRODUCTION } \\
\text { AND } \\
\text { PROCESSING } \\
31 / 03 / 2017 \\
\end{array}$ & $\begin{array}{l}\text { The project is supporting a new line of tomato production and processing. } \\
\text { The investment strengthens the Promoter's strategy to enhance the } \\
\text { competitiveness of its business through the enlargement of capacity and } \\
\text { resource efficiency. } \\
\text { Budget: Not disclosed. }\end{array}$ & Ukraine \\
\hline $\begin{array}{l}\text { COILLTE } \\
\text { SUSTAINABLE } \\
\text { FORESTRY } \\
22 / 12 / 2016\end{array}$ & $\begin{array}{l}\text { Financing of Coillte Teoranta's forest plantation establishment and } \\
\text { management program for the period 2016-2020. According to best technical } \\
\text { and environmental practice, over } 35,500 \text { ha of forest were expected to be } \\
\text { planted, the remainder being new plantations on company-owned land. It } \\
\text { also included building } 373 \mathrm{~km} \text { of new forest roads and an additional 1,288 } \\
\text { km of forest roads to be renewed. } \\
\text { EIB finance: EUR } 98 \text { million; Total Cost: EUR } 195 \text { million }\end{array}$ & Ireland \\
\hline
\end{tabular}




\begin{tabular}{|c|c|c|}
\hline $\begin{array}{l}\text { EU FUNDS CO- } \\
\text { FINANCING } \\
2014-2020 \text { (EST) } \\
2 / 12 / 2016\end{array}$ & $\begin{array}{l}\text { The plan sustained the Estonian 2014-2020 Partnership Agreement and } \\
\text { selected investments of its two implementation Programmes: (i) OP for } \\
\text { Cohesion Policy Funds (ESF, CF, ERDF); and (ii) Rural Development } \\
\text { Programme (EAFRD). The actions will focus on technological development } \\
\text { and innovations, environment, transport, research, health, improvement of } \\
\text { training and access to employment, water and environmental protection, } \\
\text { education, health, improvement of training and access to employment, small } \\
\text { infrastructure in rural areas. } \\
\text { EIB finance: EUR } 720 \text { million; Total Cost: EUR } 5700 \text { million }\end{array}$ & Estonia \\
\hline $\begin{array}{l}\text { ROMANIA EU } \\
\text { CO-FINANCING } \\
\text { FOR GROWTH } \\
2014-20 \\
15 / 07 / 2016\end{array}$ & $\begin{array}{l}\text { The project attempts to foster competitiveness through sub-projects that } \\
\text { involve RandD, innovation and human development investment in crucial } \\
\text { sectors, ICT and e-government, support for small and medium-sized } \\
\text { enterprises, employment promotion, education/training, and social } \\
\text { inclusion. } \\
\text { EIB finance: EUR } 400 \text { million; Total Cost: EUR } 7228 \text { million }\end{array}$ & Romania \\
\hline $\begin{array}{l}\text { EU FUNDS CO- } \\
\text { FINANCING } \\
2014-2020 \text { (EST) } \\
17 / 12 / 2014\end{array}$ & $\begin{array}{l}\text { The project, structured as a Structural Programme Loan, will support the } \\
\text { following sectors: technological development and innovations, environment, } \\
\text { health, water and environmental protection, transport, research, education, } \\
\text { enhancement of training and access to employment, and small infrastructure } \\
\text { rural regions. } \\
\text { EIB finance: EUR } 720 \text { million; Total Cost: EUR } 5700 \text { million }\end{array}$ & Estonia \\
\hline $\begin{array}{l}\text { EXTREMADUR } \\
\text { A GROWTH and } \\
\text { INNOVATION } \\
\text { FL } \\
28 / 11 / 2013\end{array}$ & $\begin{array}{l}\text { Framework Loan to support the public sector in the human capital, basic } \\
\text { infrastructure and RDI sectors. The scope is to contribute to employment } \\
\text { creation, fostering cohesion and social equality, and improving the } \\
\text { knowledge economy. The plan's main objectives are the further sustainable } \\
\text { development of public service delivery. } \\
\text { EIB finance: EUR } 125 \text { million; Total Cost: EUR } 437 \text { million }\end{array}$ & Spain \\
\hline $\begin{array}{l}\text { EU FUNDS CO- } \\
\text { FINANCING } \\
\text { CANTABRIA } \\
22 / 07 / 2013\end{array}$ & $\begin{array}{l}\text { The project involved investment projects supported by the Regional } \\
\text { Operational Programme, precisely Research and Development, Information } \\
\text { and Communications Technology, and Information Society projects. The } \\
\text { plan was centered on enhancing natural resources (also forestry and } \\
\text { agricultural land) and rural economy diversification. } \\
\text { EIB finance: EUR } 75 \text { million; Total Cost: EUR } 293 \text { million }\end{array}$ & Spain \\
\hline
\end{tabular}

Table 1 recommends a review of the projects supported by the European Investment Bank in the Agriculture, Fisheries, Forestry sector, covering the European area and the 2010-2021 period. As the results demonstrate, only 13 out of 73 projects funded by the EIB were explicitly related to innovation and RandD activities. Noteworthy, France has three projects funded mainly associated with the production of protein for food and feed uses from oilseed yield, bio-based materials, and the set-up of novel field crop and vegetable seed diversity. Ukraine accessed two funded projects related to grains and sugar storage capacity and tomato production and processing efficiency. Sweden and Ireland's projects were mainly related to forest management, while Estonia, Romania, and Spain initiated projects from water and environmental protection to education and training access to employment.

\section{Conclusions}

Unquestionably, the agriculture sector is required to become sustainable and resilient to generate larger quantities and higher quality of food at affordable prices while protecting the environment to face the current global challenges. RandD and innovation's role in expanding a sustainable agricultural sector have been acknowledged by organizations such as United Nations- Food and Agriculture Organization and the European Commission.

As the paper's results suggest, governments around the EU's member states recognize the value of RandD activities in the agriculture sector. Overall, in the 2010-2019 period, an average increase of $+37.4 \%$ in the allocated budget was recorded at the EU level. Among the countries with the most significant contributions in budgets as a total of 2010-2019 are Germany (EUR 7.983 million), the UK (EUR 4.352 million), Spain (EUR 4.348 million), and France (EUR 3.462 million). In terms of budgets' percentual increase the following countries' evolution worth to be remarked Croatia $(+353.2 \%)$, Malta 
$(+247.5 \%)$; Latvia (+159.14\%), Hungary $(+106.6 \%)$ and Greece $(+96 \%)$. Regarding the projects funded by the European Investment Bank in the Agriculture, Fisheries and Forestry industry, covering the European area for the 2010-2021 period, only 13 out of 73 projects included in their description terms such as "research and development", "innovation" and "technology". Limits of the current research are recognized. For the quantitative approach, part of the analyzed data was based on estimations and interpreted data. Also, the collection definitions differed among the member states. Concerning the qualitative research, terms such as "incubator", "modernization", "upgrade" were excluded.

All in all, as the current findings indicate, the EU acknowledges the role of RandD in constructing a sustainable agriculture chain. However, even though there is an upward trend in sustaining innovation activities in the agri-food sector, a more in-depth analysis at the EU's member state level is needed to formulate a clear set of recommendations. The present results act as a signal for the EU and member states' governments to review priorities and redesign the funding schemes to strengthen the agricultural sector.

\section{Acknowledgment}

The present study is part of the post-doctoral project "Analysis of the competitive sectorial position in the global business network. Romania and the agricultural sector" coordinated by the Post-Doctoral School of Economics and International Affairs.

\section{References}

Adhikari, B. and Prapaspongsa, T., 2019. Environmental Sustainability of Food Consumption in Asia. Sustainability, 11(20). Article number: 5749.

Arfini, F., Antonioli, F., Cozzi, E., Donati, M., Guareschi, M., Mancini, M. and Veneziani, M., 2019. Sustainability, Innovation and Rural Development: The Case of Parmigiano-Reggiano PDO. Sustainability, 11(18), Article number: 4978.

Ashraf, S.A., Siddiqui, A.J., Elkhalifa, A.E.O., Khan, M.I., Patel, M., Alreshidi, M., Moin, A., Singh, R., Snoussi, M. and Adnan, M., 2021. Innovations in nanoscience for the sustainable development of food and agriculture with implications on health and environment. Science of The Total Environment, 768, Article number: 144990.

Balázs, B., Kelemen, E., Centofanti, T., Vasconcelos, M.W. and Iannetta, P.P.M., 2021. Integrated policy analysis to identify transformation paths to more sustainable legume-based food and feed value-chains in Europe. Agroecology and Sustainable Food Systems, pp.1-23.

Henrik Barth, Per-Ola Ulvenblad and Pia Ulvenblad, 2017. Towards a Conceptual Framework of Sustainable Business Model Innovation in the Agri-Food Sector: A Systematic Literature Review. Sustainability, 9(9), Article number: 1620.

Bertoni, D., Cavicchioli, D., Donzelli, F., Ferrazzi, G., Frisio, D., Pretolani, R., Ricci, E. and Ventura, V., 2018. Recent Contributions of Agricultural Economics Research in the Field of Sustainable Development. Agriculture, 8(12), Article number: 200.

Blanc, S., Massaglia, S., Brun, F., Peano, C., Mosso, A. and Giuggioli, N.R., 2019. Use of Bio-Based Plastics in the Fruit Supply Chain: An Integrated Approach to Assess Environmental, Economic, and Social Sustainability. Sustainability, 11(9), Article number: 2475.

El Bilali, H., 2019. Research on agro-food sustainability transitions: A systematic review of research themes and an analysis of research gaps. Journal of Cleaner Production, 221, pp.353-364.

Elisante, F., Ndakidemi, P., Arnold, S., Belmain, S., Gurr, G., Darbyshire, I. and Stevenson, P., 2019. Enhancing knowledge among smallholders on pollinators and supporting field margins for sustainable food security. Journal of Rural Studies, 70, pp.75-86.

European Commission, 2011. Communication form the Commission to the European Parliament, the Council, the European Economic and Social Committee and the Commitee of the Regions. Horizon 
2020 - the Framework Programme for Research and Innovation. Brussels: The European Commission.

European Commission, 2018. Assessment of Research and Innovation on Food Systems by European Member States. Brussels: European Commission.

European Commission, 2018a. EU budget: the Common Agricultural Policy beyond 2020. [online] Available at: <https://ec.europa.eu/commission/presscorner/detail/en/IP_18_3985> [Accessed 17 April 2021].

European Commission, 2020. Investing in sustainable agriculture and food systems, [online] Available at: <https://ec.europa.eu/international-partnerships/topics/investing-sustainable-agriculture-andfood-systems_en> [Accessed 15 April 2021].

European Investment Bank, 2019. Feeding future generations. How finance can boost innovation in agri-food. Luxembourg: European Investment Bank.

European Investment Bank, 2021. EFSI works, [online] Available at: $<$ https://www.eib.org/en/efsi/index.htm> [Accessed 14 April 2021].

Fischer, A., Beers, P., van Latesteijn, H., Andeweg, K., Jacobsen, E., Mommaas, H. and Veldkamp, A., 2012. Transforum system innovation towards sustainable food. A review. Agronomy for Sustainable Development, 32(2), pp.595-608.

Ilieva, R. and Hernandez, A., 2018. Scaling-Up Sustainable Development Initiatives: A Comparative Case Study of Agri-Food System Innovations in Brazil, New York, and Senegal. Sustainability, 10(11), Article number: 4057.

Jones-Garcia, E. and Krishna, V.V., 2021. Farmer adoption of sustainable intensification technologies in the maize systems of the Global South. A review. Agronomy for Sustainable Development, 41(1), Article number: 8.

Lampridi, M., Sørensen, C. and Bochtis, D., 2019. Agricultural Sustainability: A Review of Concepts and Methods. Sustainability, 11(18), Article number: 5120.

Guerrero Lara, L., Pereira, L., Ravera, F. and Jiménez-Aceituno, A., 2019. Flipping the Tortilla: SocialEcological Innovations and Traditional Ecological Knowledge for More Sustainable Agri-Food Systems in Spain. Sustainability, 11(5), Article number: 1222.

Lerner, D.G., Pereira, H.M.F., Saes, M.S.M. and Oliveira, G.M. de, 2021. When Unfair Trade Is Also at Home: The Economic Sustainability of Coffee Farms. Sustainability, 13(3), Article number: 1072.

Mangla, S., Luthra, S., Rich, N., Kumar, D., Rana, N. and Dwivedi, Y., 2018. Enablers to implement sustainable initiatives in agri-food supply-chains. International Journal of Production Economics, 2013, pp.379-393.

Martucci, O., Arcese, G., Montauti, C. and Acampora, A., 2019. Social Aspects in the Wine Sector: Comparison between Social Life Cycle Assessment and VIVA Sustainable Wine Project Indicators. Resources, 8(2), Article number: 69.

Moreno-Miranda, C., Jordán, J., Moreno, R., Moreno, P. and Solis, J., 2019. Protected Designation of Origin and Sustainability Characterization: The Case of PDO Cocoa Arriba. Agriculture, 9(10), Article number: 229.

Naik, G. and Suresh, D., 2018. Challenges of creating sustainable agri-retail supply chains. IIMB Management Review, 30(3), pp.270-282.

Nastis, S.A., Mattas, K. and Baourakis, G., 2019. Understanding Farmers' Behavior towards Sustainable Practices and Their Perceptions of Risk. Sustainability, 11(5), Article number: 1303.

Patidar, R., Agrawal, S. and Pratap, S., 2018. Development of novel strategies for designing sustainable Indian agri-fresh food supply chain. Sādhanā, 43(10), Article number: 167. 
Pérez-Mesa, J.C., Piedra-Muñoz, L., García-Barranco, M.C. and Giagnocavo, C., 2019. Response of Fresh Food Suppliers to Sustainable Supply Chain Management of Large European Retailers. Sustainability, 11(14), Article number: 3885.

Pippinato, L., Blanc, S., Mancuso, T. and Brun, F., 2020. A Sustainable Niche Market: How Does Honey Behave? Sustainability, 12(24), Article number: 10678.

Pullman, M., Maloni, M. and Dillard, J., 2010. Sustainability Practices in Food Supply Chains: How is Wine Different? Journal of Wine Research, 21(1), pp.35-36.

Rana, R.L., Tricase, C. and De Cesare, L., 2021. Blockchain technology for a sustainable agri-food supply chain. British Food Journal, [online] ahead-of-print(ahead-of-print). https://doi.org/10.1108/BFJ-09-2020-0832.

Salazar, O., Rojas, C., Baginsky, C., Boza, S., Lankin, G., Munoz-Saez, A. and Altieri, M., 2020. Challenges for agroecology development for the building of sustainable agri-food systems. International Journal of Agriculture and Natural Resources, 47(3), pp.152-158.

Sharpe, R. and Barling, D. 2019. The right thing to do': ethical motives in the interpretation of social sustainability in the UK's conventional food supply. Symposium on Ethics and Sustainable AgriFood Governance / 27th Annual Congress of the European-Society-for-Rural-Sociology (ESRS). Krakow, Poland: Agriculture and Human Values.

Trivellas, P., Malindretos, G. and Reklitis, P., 2020. Implications of Green Logistics Management on Sustainable Business and Supply Chain Performance: Evidence from a Survey in the Greek AgriFood Sector. Sustainability, 12(24), Article number: 10515.

Ulvenblad, P., Ulvenblad, P. and Tell, J., 2019. An overview of sustainable business models for innovation in Swedish agri-food production. Journal of Integrative Environmental Sciences, 16(1), pp.1-22.

United Nations, 1987. Our Common Future: Report of the World Commission on Environment and Development. Oslo: The United Nations. [pdf] Available at: $<$ https://sustainabledevelopment.un.org/content/documents/5987our-common-future.pdf> [Accessed 14 April 2021].

United Nations, 2015. United Nations Global Sustainable Development Report. New York, USA: United Nations.

United Nations, 2019. World Population Prospects 2019: Ten Key Findings. Departament of Economic and Social Affairs. [pdf] Available at: $<$ https://population.un.org/wpp/Publications/Files/WPP2019_10KeyFindings.pdf> [Accessed 16 April 2021].

Van Pham, L. and Smith, C., 2014. Drivers of agricultural sustainability in developing countries: a review. American Journal of Agricultural Economics, 34, pp.326-341.

Vasa, L., Angeloska, A. and Trendov, N., 2018. Comparative analysis of circular agriculture development in selected Western Balkan countries based on sustainable performance indicators. Economic Annals - XXI, 168(11-12), pp.44-47.

Vermunt, D., Negro, S., Van Laerhoven, F., Verweij, P. and Hekkert, M., 2020. Sustainability transitions in the agri-food sector: How ecology affects transition dynamics. Environmental Innovation and Societal Transitions, 36, pp.236-249.

Yadav, S., Luthra, S. and Garg, D., 2021. Modelling Internet of things (IoT)-driven global sustainability in multi-tier agri-food supply chain under natural epidemic outbreaks. Environmental Science and Pollution Research, 28(13), pp.16633-16654.

Zollet, S. and Maharjan, K.L., 2021. Overcoming the Barriers to Entry of Newcomer Sustainable Farmers: Insights from the Emergence of Organic Clusters in Japan. Sustainability, 13(2), Article number: 866. 